\title{
THE IMPACT OF SOCIALLY RESPONSIBLE INVESTMENT INDEX Constituent Announcements on Firm Price: EVIDENCE FROM THE JSE
}

\author{
Olga Gladysek and Chimwemwe Chipeta \\ School of Economic and Business Sciences, University of the Witwatersrand
}

Accepted: August 2012

\begin{abstract}
This paper examines whether Socially Responsible Investment (SRI) Index constituent announcements have any impact on the returns of firms listing on the JSE SRI Index. The event study methodology is utilised to estimate abnormal returns for the firms included in the Index. The results indicate insignificant average abnormal returns (AARs) for the years 2004, 2006, 2007, 2008 and 2009, suggesting no significant shareholder gains over the entire event window. However, the year 2005 is associated with positive and significant abnormal returns. Post announcement cumulative average abnormal returns (CAARs) are positive for the years 2005 and 2007. However, the year 2008 exhibited extreme swings in CAARs with a general declining trend in the latter part of the event window. These swings are attributed to the global financial crisis of 2008. Furthermore, the cumulative returns for the total sample show no clear outperformance of the SRI over the JSE All Share Index.
\end{abstract}

Key words: abnormal returns, event study, JSE, socially responsible index

JEL: G14

\section{1}

\section{Introduction}

The Johannesburg Stock Exchange (JSE) implemented the Socially Responsible Investment (SRI) Index in May 2004. Some of the key objectives of the SRI Index are to recognise the companies that deliver on the triple bottom line (economic, social and governance reporting), and to provide a benchmark for comparing socially responsible and non-socially responsible companies. In order to participate on the Index, firms are required to meet certain criteria, which are continuously being updated and improved. The SRI Index can therefore be viewed as a credible Corporate Social Responsibility (CSR) signal for investors who wish to invest in a responsible manner.

In pursuit of this argument, it is imperative to test whether SRI constituent announcements have a significant effect on the value of the firms listing on the Index. Fama (1991) affirms that, if market efficiency is maintained, then the value of the firm should change when new information enters the market. Assuming that investors perceive the listing of a firm as part of the SRI Index as new information, share prices are expected to react in response to the addition of companies on the Index. The empirical relationship between CSR and shareholder wealth has primarily focused on Black Economic Empowerment (BEE) deal announcements and short and long-term shareholder wealth. For example, Sartorius and Wolmarans (2009) examined the short-term wealth effects of BEE transaction announcements on the JSE for the period 2002-2006. Additionally, Ward and Muller (2010) studied both the short and long-term wealth effects of BEE transactions on the JSE. Similarly, Chipeta and Vokwana (2011) used non-parametric tests to test the significance of these transactions during the period 1999-2009. A notable empirical study that is closely related to this analysis was conducted by Viviers, Bosch, Smit and Buijs (2008). They examined the risk adjusted returns of various Responsible Investment (RI) funds in South Africa for the period 19922006, and found that, over time, RI fund performance improved relative to their benchmark indices. The constitution of the SRI Index allows for further analysis of the 
performance of the firms listing on to the Index. This paper therefore adds to the existing empirical work by examining two issues: The first issue relates to whether JSE SRI Index constituent announcements have a significant effect on the abnormal returns of the firms listing on the Index for the years 2004-2009. The second issue relates to whether the overall SRI index outperformed the JSE All Share Index (ALSI) for the years 2004-2009.

The results indicate insignificant average abnormal returns (AARs) for the years 2004, 2006, 2007, 2008 and 2009, suggesting that there are no significant shareholder gains over the entire event window. However, the year 2005 is associated with positive and significant abnormal returns. Post announcement cumulative average abnormal returns (CAARs) are positive for the years 2005 and 2007. The year 2008 exhibited extreme swings in CAARs, with a general declining trend in the latter part of the event window. These swings are attributed to the global financial crisis of 2008. Furthermore, the JSE SRI Index outperformed the JSE All Share Index (ALSI) only for the year 2004. However, insignificant outperformance was documented for the rest of the years and for the total sample.

The remainder of the paper is organised as follows: Section two discusses the literature review. Section three describes the data used and the research methodology. Section four reports the main results, and Section five concludes the paper.

\section{2}

\section{Literature review}

\subsection{SRI Index performance}

The first approach in determining SRI performance is one that evaluates socially responsible indices. SRI indices were established to allow investors to trade shares of companies which are deemed to be socially responsible. These indices include the FTSE4Good, JSE SRI, Domini-400 Index and the Dow Jones Sustainability Group Index (DJSGI). These indices provide reassurance for investors and fund managers that the constituent companies are screened, monitored and assessed according to the objective ESG criteria.

\subsubsection{Global SRI performance}

Knoepfel (2001) compared the Dow Jones Global Index (DJGI) World to the Dow Jones Sustainability Group Index (DJSGI) World and found that the DJSGI World outperforms the DJGI World in terms of average returns on equity, assets and investments. This finding illustrates that, in some cases, choosing a sustainability-driven Index can yield superior results in comparison with a regular equity Index.

Alternatively, Cerin and Dobers (2001) reviewed the structure, transparency and performance of the DJSGI World compared with the DJGI World. They found that, in terms of financial performance, the sustainability global Index performed better than the ordinary global Index. The market capitalisation of the DJSGI World is two and a half times greater than that of the DJGI World. On the other hand, the DJSGI World focuses more on the technology sector. Both these facts are cited as reasons for the discrepancy in the performance between these indices. These reasons are a cause for concern as the aforementioned authors deem these factors as the cause of the outperformance rather than ESG standards being managed effectively.

In another study, Dilling (2008) examined whether abnormal returns in subsequent years were experienced when companies were added to the DJSGI World Index for the period 20012005. The study found that newly-added companies experienced abnormal returns of 2 per cent in the year 2002 but this abnormal return decreased in the subsequent years. This conclusion is a matter for concern, as the concept of corporate social responsibility is growing in popularity worldwide. These results could have occurred because the criteria for CSR reporting are not standardised or regulated. This makes it difficult for the investor to determine the quality of CSR reporting.

Schröder (2007) examined the performance of 29 SRI indices and found that SRI indices neither underperformed nor outperformed their respective benchmarks. This finding is somewhat surprising, as screening investments according to socially responsible principles decreases the investment universe from which stocks are picked. Portfolio management theory dictates that a restricted selection of stocks should lead to lower risk-adjusted returns. The Sharpe ratio 
was incorporated into the study and indicated that some SRI indices exhibited a higher risk profile than standard equity indices. This finding confirms that a risk assessment should be undertaken when considering investing in a socially responsible Index.

\subsubsection{European SRI performance}

Since 2008, the European SRI market has experienced a remarkable growth of about 87 per cent over a period of two years (Eurosif, 2010). This booming industry has prompted various researchers to analyse SRI performance in Europe. For example, Curran and Moran (2007) examined the financial performance of companies that were added to or deleted from the FTSE4Good UK Index for the period 1999 - 2002. The authors provide evidence that the market reacted negatively to a firm's exclusion from the Index, and positively when a firm was added. However, these findings were insignificant, implying that there was no abnormal financial gain for firms that had been listed on the Index over their sample period.

Collison, Cobb, Power and Stevenson (2008) extended the sample period used in Curran and Moran's (2007) study, and tested whether the FTSE4Good Indices outperformed their relative benchmarks. They show that the FTSE4Good Indices outperformed their relative benchmarks over a sample period of 1996-2005. However, this outperformance is attributed to a risk differential between the two indices. Both of these studies thus conclude that investors who invested in the FTSE4Good indices can perform better than investors who do not follow a socially responsible investment trading strategy.

\subsubsection{American SRI performance}

Sauer (1997) analysed the performance of the DSI-400 against two unrestricted benchmark portfolios in the United States, and concluded that screening investments in a social context does not necessarily have a negative impact on performance. Additionally, Statman (2000) compared the performance of the Standard \& Poor's 500 Index (S\&P 500) to the Domini Social Index (DSI-400) for the period between 1990 and 1998, and established that the DSI400 had slightly higher raw returns. However, when risk-adjusted returns were taken into account, the DSI 400 underperformed the S\&P 500, although this underperformance was insignificant.

To conclude, the results of the aforementioned studies suggest that, in some instances, investors may have the incentive to invest in SRI indices, as the performance of the sustainability indices is generally higher than that of the general equity Index. The financial goal of reaping the bottom line may therefore be achieved with the additional benefit of being able to target companies that are concerned for their stakeholders and the environment in which they operate. In addition, SRI indices are accessible to investors and can be used as a social screening mechanism much like a fund or trust. However, the investor needs to examine the relative risk of the SRI Index, as risk is a primary investment concern.

\subsection{SRI share price performance}

Previous studies have documented a link between CSR and financial performance. This is the second approach whereby SRI company performance is tested to determine how it fares against non-SRI company performance. The discussion on SRI stock performance is divided into positive, negative and environmental SRI performance.

\subsubsection{Positive SRI performance}

A positive relationship between CSR and financial performance is documented by Cochran and Wood (1984) after controlling for the average age of corporate assets. In a further assessment of the relationship between corporate social performance and financial performance, Waddock and Graves (1997) found that a link exists between current corporate social performance and financial performance. The authors also conclude that firms that employ socially responsible measures in the short term will reap benefits in the form of improved financial performance in the future.

Furthermore, Kempf and Osthoff (2007) studied the effects of SRI stock selection on portfolio performance, and demonstrated that the strategy of purchasing stock with a high SRI rating and selling stock with a lower rating provides exceptional returns. The highest abnormal return achieved in this study was 8.7 per cent, which occurred when stocks were screened on a best-in-class screening method. The conclusion reached in this analysis is that 
not only are SRI stocks able to outperform the market by a significant margin, but they also outperform the market when reasonable transaction costs are taken into consideration.

\subsubsection{Negative SRI performance}

In general, the negative SRI performance has been documented with respect to studies that examined philanthropy and disinvestment. Seifert, Morris and Bartkus (2003) conducted an investigation into corporate philanthropy and documented a negative relationship between corporate giving and financial performance. This result indicates that, in certain instances, companies that behave in a socially responsible manner may be penalised.

The Apartheid era in South Africa led numerous companies to disinvest from the country as a form of CSR (Lansing \& Kuruvilla, 1988). An analysis of the announcement of publicly-traded firms disinvesting from South Africa was performed by Wright and Ferris (1997), who found that the Apartheid disinvestment strategy yielded significant negative excess returns.

\subsubsection{Environmental SRI performance}

Several authors have used environmental performance as a proxy for CSR. The findings of studies that include an environmental variable are explored in this section. Stanwick and Stanwick (1998) conducted a study incorporating firm size, environmental performance and financial performance variables. The authors found a relationship between firm size, the level of profitability and the amount of polluting emissions that a firm releases. The use of pollutant emissions as a proxy for environmental impact may be viewed as a limitation. This is because low emission industries that do tangible harm to the environment may not be classified as having a high impact on the environment.

Likewise, Klassen and McLaughlin (1996) document the link between environmental management and financial performance by testing firm-specific events pertaining to environmental occurrences. Firm financial performance was analysed on the basis of whether a company either won an environmental award (positive information, suggesting strong environmental performance) or experienced an environmental crisis (negative information, suggesting weak environmental performance). The findings of this study were consistent with the hypothesis proposed which stated that there is a correlation between strong environmental performance and positive abnormal returns.

From the preceding lines of argument, it is evident that companies need to be aware of their impact on the environment, and they need to control for environmental risks accordingly because investors value such behaviour.

\subsection{South African SRI performance}

The empirical research that has been conducted on the SRI in South Africa focuses mostly on the challenges facing the industry, and mostly examining the broader aspect of CSR. Heese (2005) highlights the fact that the lack of a formal and universally understood definition of the meaning of SRI is inhibiting the growth of the SRI sector in South Africa. An element of this definition which is especially problematic and pertinent to South Africa is how BEE is defined and how it relates to the concept of SRI.

Herringer, Firer and Viviers (2009) conducted semi-structured interviews with investment professionals from both buy and sell-side backgrounds. This analysis was performed in order to gauge the challenges facing CSR in South Africa. The interviewees highlighted the fact that more SRI products, funds and investments are required to spur growth in this developing industry. The key challenges that have been argued to hinder industry growth are the negative perception of achieving a below-average return, the amount of human capital required to screen investments, the limited SRI universe, the lack of accessibility to SRI infor-mation and the lack of pension fund interest. Viviers, Bosch, Smit and Buijs (2009) cite two challenges facing the South African SRI landscape. The first relates to the relatively small size of the SRI industry in South Africa, and the second is the institutional investors' lack of interest in committing substantial investments into the SRI stocks. In terms of performance, Viviers et al. (2008) tested the risk adjusted returns of RI funds in South Africa and they found that these funds did not consistently outperform their relative benchmark indices over the period of analysis. Specifically, local RI funds underperformed their relative benchmark indices in 
some sub periods, while outperformance was documented in another sub period.

\section{3}

\section{Data and methodology}

\subsection{Data}

The sample period used is from May 2004 (when the SRI Index was first implemented on the JSE) to November 2009. The data for this study were sourced from the i-Net Bridge database. ${ }^{1}$ The number of firms examined is $38,37,45,47,55$ and 63 for the years 2004 to 2009 respectively. Companies for which no observations could be found were omitted for that particular year. Various industries are represented in the SRI Index, including: mining, retail, finance and construction.

\subsection{The event study methodology}

The event study methodology has been used by researchers to assess the effects of events on share prices. MacKinlay (1997) describes the event study methodology as a credible way to capture the extent to which investors value a firm when their assessment of a firm changes. This change in investor assessment is due to an inflow of new information into the market. Moreover, Ruf et al. (2001) argue that event studies have documented a consistent association between poor corporate social performance and negative abnormal returns. If an event, such as the announcement of the constituents of an SRI Index, has no effect on the market, then the abnormal return of the companies listed on the Index should remain unchanged. If, however, the announcement does affect the share prices of the listed companies, the abnormal returns reflect the markets' reaction to the arrival of this new information.

In order to draw reasonable conclusions from the results, the following assumptions are made: markets are efficient, there are no confounding effects during the event window analysed and the announcement was unanticipated by market agents. Daily abnormal share returns are used as a proxy for financial performance and the SRI Index is used as a proxy for CSR. The event window consists of 20 trading days prior to the announcement and 20 trading days after the announcement, including the announcement date (Day 0). The total number of days in the event window is 41. The 41-day event window $(-20,+20)$ is used to ensure that the investors have time to react to the news of the relevant firm being included in the Index. ${ }^{2}$ Following Curran and Moran (2007), share returns are calculated as follows:

$$
R_{j t}=\ln \left({ }^{P_{j t}} / P_{j t-1}\right),
$$

where $\mathrm{R}_{\mathrm{jt}}$ is the share return of firm $j$ on day $t$. $\mathrm{P}_{\mathrm{jt}}$ is the share price of firm $j$ on day $t$ and $\mathrm{P}_{\mathrm{jt}-1}$ is the share price of firm $j$ on day $t-1$. Curran and Moran (2007) utilised the market model when generating expected returns. In this study, the theoretical framework of the Capital Asset Pricing Model (CAPM) is utilised in generating returns. This approach is followed in order to incorporate a market benchmark. The inclusion of a market benchmark, in this case the JSE All Share Index (ALSI), allows inferences to be made to compare the performance of the SRI Index relative to the South African market.

The expected returns are derived as follows:

$$
E\left(R_{j t}\right)=\alpha_{j}+\beta_{j}\left(R_{m t}-R_{r f}\right),
$$

where $R_{m t}$ is the return on the market Index (ALSI) for day $t$. The $\alpha_{\mathrm{j}}$ represents the intercept of the regression and $\beta_{\mathrm{j}}$ represents the slope of the regression. In order to generate unbiased $\alpha$ and $\beta$ estimates for each SRI constituent firm, returns are computed from 100 trading days prior to the announcement date up to 20 trading days post announcement date, (-100, +20). The 90-day Banker's Acceptance Rate is used as a proxy for the risk-free rate $\left(\mathrm{R}_{\mathrm{rf}}\right)$.

The abnormal returns (AR) are calculated as follows:

$$
A R_{j t}=R_{j t}-E\left(R_{j t}\right),
$$

where $\mathrm{AR}_{\mathrm{jt}}$ is the unexpected return for firm $j$ on day $t$. $\mathrm{R}_{\mathrm{jt}}$ is the normal return for firm $j$ on day $t$ and $\mathrm{E}\left(\mathrm{R}_{\mathrm{jt}}\right)$ is the expected return for firm $j$ on day $t$. The difference between the actual and expected return yields the abnormal return. The resultant value, $\mathrm{AR}_{\mathrm{jt}}$, is therefore an indication of share price movements caused by an event. An example of such an event would be the addition or deletion of companies on the SRI Index. If the event had no impact on the share price, the abnormal return would subsequently equal zero. 
The average ARs are calculated according to the following specification:

$$
\mathrm{AR}_{\mathrm{t}}=\sum^{\mathrm{AR}_{\mathrm{jt}}} /_{\mathrm{N}} \text {, }
$$

where $\mathrm{N}$ represents the number of firms in the sample, in each given year. Share returns can be noisy and therefore the abnormal returns are averaged.

\section{4}

\section{Discussion of results}

\subsection{Basic results}

The descriptive statistics of the study are reported in Table 1. It is evident that the 2008 year had the highest standard deviation value. The announcement of the constituents of the SRI Index took place on 26 November of that year. The increased risk in 2008 can therefore be attributed to the world financial crisis, which was at its peak in the last quarter of 2008 (Naudé, 2009). The extreme minimum and maximum values (-1.424 per cent, 1.932 per cent) in the 2008 period signify increased volatility of returns during the business cycle trough. Comparatively, the standard deviation measures in the rest of the sample are significantly lower, with 2009 showing the lowest measure at a value of 0.118 per cent.

Table 1

Descriptive statistics

\begin{tabular}{|c|c|c|c|c|c|}
\hline Year & \multicolumn{1}{|c|}{ Mean } & Median & \multicolumn{1}{c|}{ Std Dev } & \multicolumn{1}{c|}{ Min } & Max \\
\hline 2004 & -0.008 & -0.031 & 0.407 & -1.064 & 0.118 \\
\hline 2005 & 0.098 & 0.114 & 0.277 & -0.593 & 0.637 \\
\hline 2006 & -0.030 & -0.039 & 0.300 & -0.854 & 0.786 \\
\hline 2007 & 0.058 & 0.063 & 0.317 & -0.658 & 0.871 \\
\hline 2008 & 0.094 & 0.023 & 0.928 & -1.424 & 1.932 \\
\hline 2009 & 0.016 & 0.018 & 0.118 & -0.247 & 0.271 \\
\hline
\end{tabular}

Figure 1 illustrates the AARs for the SRI Index for the years 2004-2006. The AARs for 2004 and 2005 exhibit a decrease before the announcement date and an increase after the announcement date. The most significant increase in AARs was experienced in 2004, which could be attributed to a short-lived shareholder interest in the new Index. Figure 2 shows AARs for the SRI Index for the years 2007-2009. The greatest post announcement increase in returns can be observed in 2008. The substantial variability in the 2008 observations, during the event window, is due to the economic uncertainty of the market during that time. The remaining years display abnormal returns, which are generally concentrated around the zero return mark for the sample period.

According to MacKinlay (1997), if the daily AARs exceed 2.5 per cent, then the announcement is perceived as good news. If the AARs are below -2.5 per cent, it is perceived as bad news. If the AARs are within the -2.5 per cent to 2.5 per cent bracket, the announcement is perceived as no news. It is clear from the AARs and CAARs that at no point during the sample period do the abnormal returns exceed 2.5 per cent or fall short of -2.5 per cent. This result indicates that, when the constituents of the SRI Index are announced, the market perceives this information as no news.

This observation suggests that the phenomenon of making socially responsible investment choices has not affected the South African market as it has done abroad. This may be due to the relatively small size of the market in South Africa. Direct implications of the small market size are thinly-traded shares (Van Rensburg \& Robertson, 2003).

The market reaction to an event may therefore not be detected because of the minimal trading volume on the Index. Another potential explanation for this finding is that investors are unaware that the Index exists or are misguided in believing that they will earn an inferior return if they choose an SRI Index over a general equity Index. 
Figure 1

Average abnormal returns of the SRI Index for 2004-2006

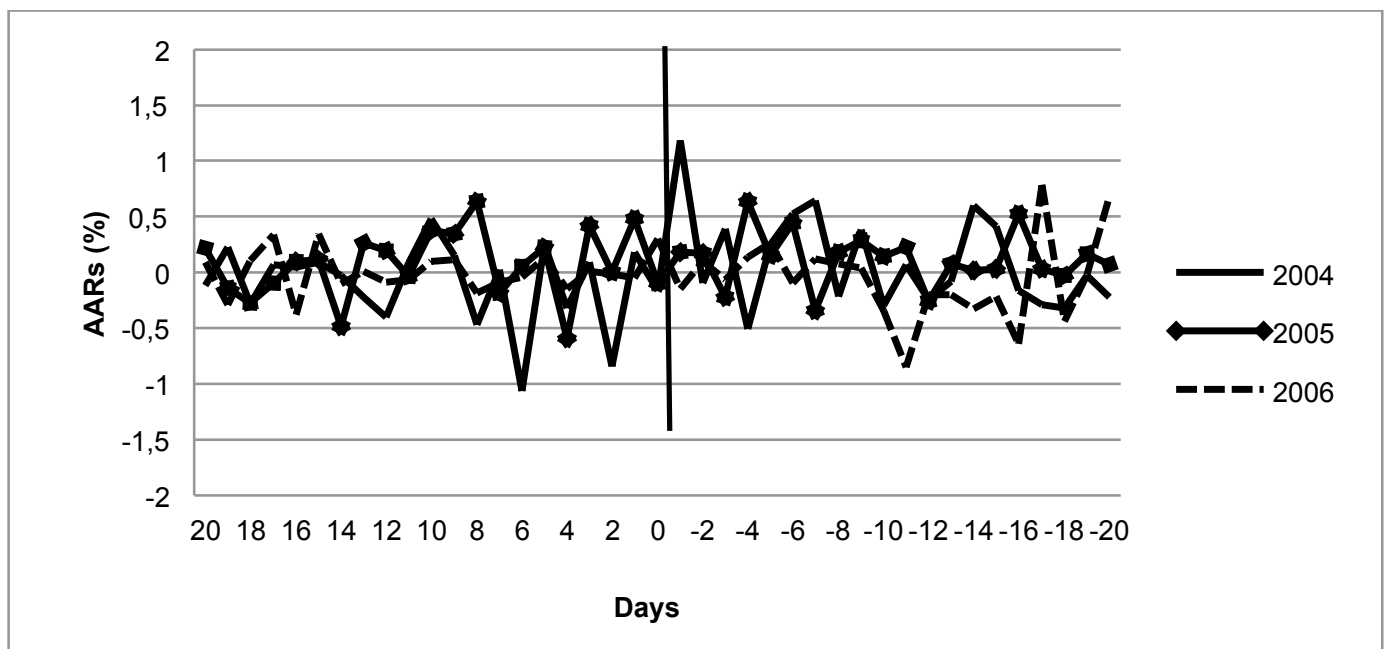

Notes: Average abnormal returns observed from 20 days prior to the announcement date to 20 days post announcement day (41-day event window).

Figure 2

Average Abnormal Returns of the SRI Index for 2007 to 2009

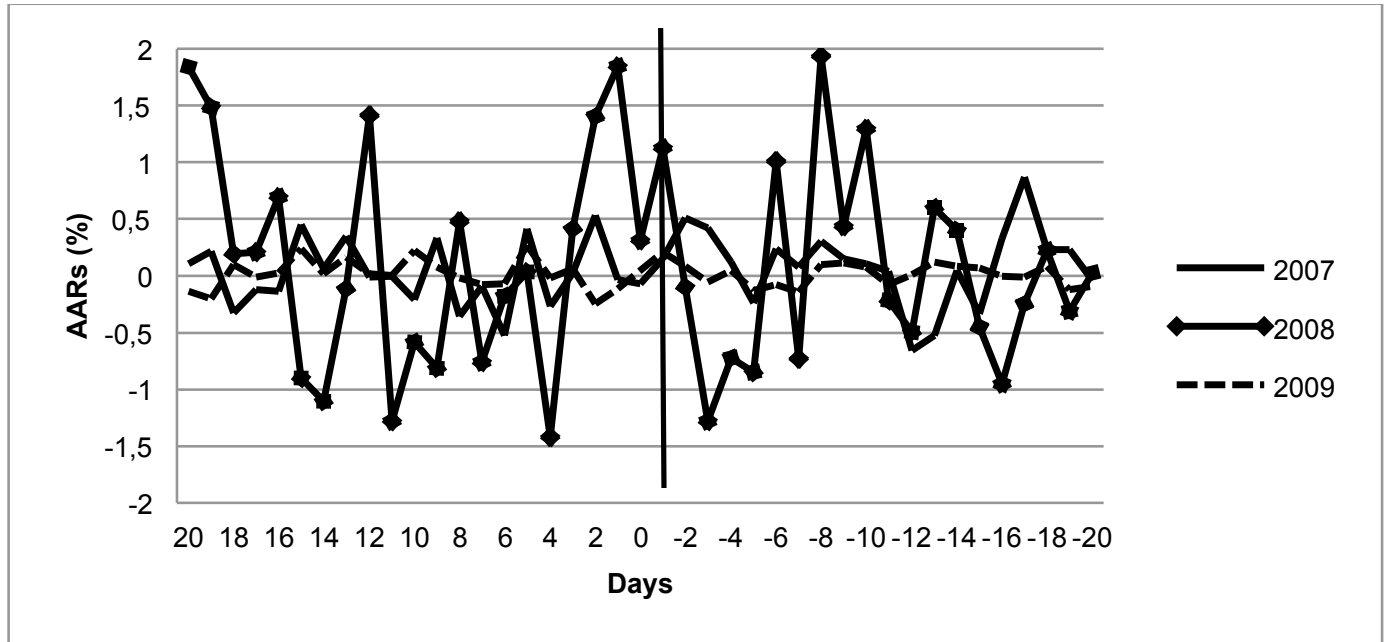

Notes: Average abnormal returns observed from 20 days prior to the announcement date to 20 days post announcement day (41-day event window).

Figure 3 displays CAARs for the years 20042009. In 2004, the CAARs displayed a downward trend from a return of -0.117 per cent at Day -20 to a return of -2.219 per cent at the announcement date. However, post announcement returns increase to the level of 0.222 per cent at Day +20 . At announcement date, the highest CAAR can be observed in 2008 with a return of 3.174 per cent, whereas the lowest return occurred in 2004, with a return of -2.219 per cent. The year 2008 exhibited positive CAAR values over the sample period, with the exception of negative returns on Day 3 and Day 4. 
Figure 3

Cumulative average abnormal returns (CAARs) of the SRI Index

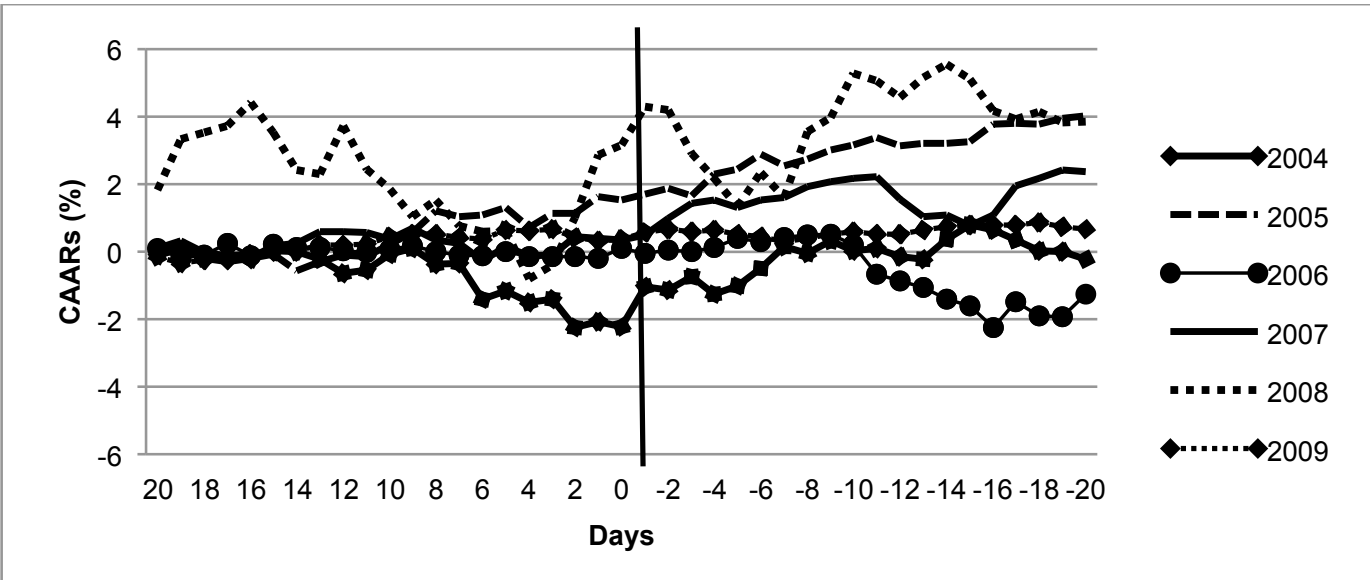

Notes: Cumulative Average Abnormal Returns observed from 20 days prior the announcement date to 20 days post announcement day (41-day event window).

\subsection{Empirical results}

The AARs for each year are stationary and modest autocorrelation is present. As the autocorrelation of the daily AARs is not extreme, independence is assumed when conducting parametric tests. The sample of the number of constituent firms for each year is sufficiently large and the data displays moderate non-normalities. Parametric one sample t-tests were run in order to determine the significance of the AARs from the period 2004-2009. The null hypothesis applied to the one sample t-test is that AARs are equal to zero. Parametric tests were therefore conducted under the normality assumption. ${ }^{3}$ Nonparametric tests relax the stringent assumptions of parametric tests and were conducted to compare whether the results of these tests would yield the same conclusion.

Table 2

Parametric and non-parametric tests

\begin{tabular}{|l|c|c|c|c|c|c|}
\hline \multirow{2}{*}{ Year } & \multicolumn{2}{|c|}{ Parametric Test } & \multicolumn{4}{c|}{ Non-Parametric Tests } \\
\cline { 2 - 7 } & \multicolumn{2}{|c|}{ Students t Test } & \multicolumn{2}{c|}{ Sign Test } & \multicolumn{2}{c|}{ Wilcoxon Signed Rank Test } \\
\cline { 2 - 7 } & Statistic & p-value & Statistic & p-value & Statistic & p-value \\
\hline 2004 & -0.121 & 0.904 & -1.5 & 0.755 & -21.5 & 0.784 \\
\hline 2005 & 2.265 & 0.029 & 8.5 & 0.012 & 177.5 & 0.020 \\
\hline 2006 & -0.647 & 0.521 & -2.5 & 0.533 & -59.5 & 0.448 \\
\hline 2007 & 1.170 & 0.249 & 3.5 & 0.349 & 95.5 & 0.220 \\
\hline 2008 & 0.649 & 0.520 & 0.5 & 1.000 & 29.5 & 0.707 \\
\hline 2009 & 0.881 & 0.384 & 2.5 & 0.533 & 65.5 & 0.403 \\
\hline
\end{tabular}

Table 2 indicates that, in all the years, with the exception of $2005(p=0,029)$, the AARs have insignificant $p$-values. The null hypothesis therefore fails to be rejected for all years with the exception of 2005 at a 95 per cent confidence interval. It can therefore be concluded that the AARs equal zero over the larger portion of the sample with the exception of
2005, when the AARs exceeded zero.

As the data displayed slight non-normalities and minimal autocorrelation, non-parametric tests (Sign and Wilcoxon Signed Rank test) were run to correct these assumption violations. The Wilcoxon Signed Rank test is more advanced than the Sign test, as not only does it compare whether AARs are significantly 
different from zero but it also measures the extent to which the returns deviate from the median value.

The Sign test hypothesis states that the median value of the AARs is equal to zero. In all the years, except for 2005, the null hypothesis fails to be rejected at a 95 per cent confidence interval. The null hypothesis is rejected in 2005, illustrating that AARs are statistically distinguishable from zero. This non-parametric test yields identical conclusions when contrasted with the Wilcoxon Signed Rank Test.

Table 3

Summary of results

\begin{tabular}{|l|l|l|l|}
\hline \multirow{2}{*}{ Year } & \multirow{2}{*}{ Direction of average AR } & \multicolumn{2}{c|}{ Significance $(\mathbf{p}<\mathbf{0 , 0 5})$} \\
\cline { 4 - 5 } & Negative & None & Non-parametric tests \\
\hline 2004 & Positive & Significant & None \\
\hline 2005 & Negative & None & Significant \\
\hline 2006 & Positive & None & None \\
\hline 2007 & Positive & None & None \\
\hline 2008 & Positive & None & None \\
\hline 2009 & & & None \\
\hline
\end{tabular}

Table 3 reports summary results from both sets of parametric and non-parametric tests. All the AARs are insignificantly different from zero. From the results presented, it can be deduced that, although the SRI Index does not earn significant average AARs, the Index does not underperform the market. On balance, it appears that the perception of the announcement is mixed. Relatively speaking, additions to the
SRI Index can be considered good news, as the majority of the mean average AARs yield positive values. However, as the statistics associated with these returns are insignificant (with the exception of 2005), it can be inferred that no financial gain greater than the market return was achieved if an investor invested in the SRI Index over the window period.

Table 4

JSE ALSI and JSE SRI CAR at day +20

\begin{tabular}{|l|c|c|}
\hline \multicolumn{1}{|c|}{ Variable } & CAR at day +20 & P value \\
\hline 2004_ALSI & -0.0019 & \\
2004_SRI & 0.0115 & $0.0450^{\star *}$ \\
\hline 2005_ALSI & 0.0054 & \\
2005_SRI & 0.0107 & 0.9068 \\
\hline 2006_ALSI & 0.0335 & \\
2006_SRI & 0.0357 & 0.6629 \\
\hline 2007_ALSI & -0.0001 & \\
2007_SRI & 0.0046 & 0.9957 \\
\hline 2008_ALSI & -0.0115 & \\
2008_SRI & -0.0001 & 0.8868 \\
\hline 2009_ALSI & -0.0149 & \\
2009_SRI & -0.0162 & 0.8649 \\
\hline Total CAR_ALSI & 0.0017 & \\
\hline Total CAR_SRI & 0.0077 & 0.5508 \\
\hline
\end{tabular}

\subsection{A comparison of the SRI and JSE index performances}

Table 4 compares the Cumulative Average Returns (CARs) for the JSE ALSI and SRI indices at day $+20 .{ }^{4}$ The SRI Index outperforms the JSE ALSI for the years 20042007. However, the outperformance is significant only for the year 2004. The associated p-value 
is statistically significant at the 5 per cent level. This significant outperformance could be associated with the enthusiasm associated with the launch of the SRI Index. The cumulative returns for the years 2008 and 2009 are negative for both indices, highlighting the negative effects associated with the global financial crisis of 2008. Overall, it appears that there is no clear SRI outperformance during the sample period, as evidenced by the p-value of 0.5508 for the total sample period.

\section{5}

\section{Limitations and suggestions for future research}

The analysis in this paper is limited to shortterm shareholder wealth returns around the announcement dates. Future research could analyse the share price and operating performance of SRI Index listed firms over a longer time period to gauge whether the industry is becoming a more prominent feature in the South African market. Additionally, researchers could investigate whether investors perceive deletions of companies from the Index as negative information.

\section{6}

\section{Conclusion}

This paper examined the effects of SRI constituents announcements on the shareholder wealth of firms listed on the Index. An event study methodology was employed, and, with the exception of the year 2005, investors do not earn any significant abnormal returns when investing in the SRI Index around the time when constituents are announced. Furthermore, the SRI outperforms the JSE ALSI only in the year 2004. This outperformance attributed to the enthusiasm for the establishment could be of the Index. However, in the following years, no significant outperformance is documented. Overall, the announcement event is considered as no news entering the market.

\section{Endnotes}

1 Licensed to the University of the Witwatersrand.

2 Two other event windows are included in a separate analysis. These are -5 to +5 days, -1 to +1 days, and the results are insignificant.

3 The output of the assumption tests is available upon request.

4 The 2004 returns for the SRI index were calculated for the 20 days after the announcement date. The returns for the following years were calculated for the 41-day event window.

\section{References}

CERIN, P. \& DOBERS, P. 2001. What does the performance of the Dow Jones sustainability group Index tell us? Eco-Management and Auditing, 8(3):123-133.

CHIPETA, C. \& VOKWANA, T.Z.C. 2011. The impact of black economic empowerment transactions on shareholder wealth and profitability: Evidence from the JSE. African Finance Journal, 13 (Special Issue): 71-91.

COCHRAN, P.L. \& WOOD, R.A. 1984. Corporate social responsibility and financial performance. The Academy of Management Journal, 27(1):42-56.

COLLISON, D.J., COBB, G., POWER, D.M. \& STEVENSON, L. A. 2008. The financial performance of the FTSE4Good indices. Corporate Social Responsibility and Environmental Management, 15(1):14-28.

CURRAN, M. \& MORAN, D. 2007. Impact of the FTSE4Good Index on firm price: An event study. Journal of Environmental Management, 82(4):529-537.

DILLING, P.F.A. 2008. The effect of the inclusion to the Dow Jones Sustainability World Index on Firm value - an empirical event study. New York Institute of Technology, Canada.

EABR \& TLC Conferences Proceedings, Rothenburg, Germany.

EUROSIF. 2010. European SRI study. Available at: http://www.eurosif.org/publications/sri_studies. [accessed 2011-03-07].

FAMA, E.F. 1991. Efficient capital markets. The Journal of Finance, 46(5):1575-1617.

HEESE, K. 2005. The development of socially responsible investment in South Africa: Experience and evolution of SRI in global markets. Development Southern Africa, 22(5):729-739. 
HERRINGER, A., FIRER, C. \& VIVIERS, S. 2009. Key challenges facing the socially responsible investment (SRI) sector in South Africa. Investment Analysts Journal, 70:11-26.

KEMPF, A. \& OSTHOFF, P. 2007. The effect of socially responsible investing on portfolio performance. European Financial Management, 13(5):908-922.

KLASSEN, R.D. \& McLAUGHLIN, C.P. 1996. The impact of environmental management on firm performance. Management Science, 42(8):1199-1214.

KNOEPFEL, I. 2001. Dow Jones Sustainability Group Index: A global benchmark for corporate sustainability. Corporate Environmental Strategy, 8(1):6-15.

LANSING, P. \& KURUVILLA, S. 1988. Business divestment in South Africa: In who's best interest? Journal of Business Ethics, 7(8):561-574.

MACKINLAY, A.C. 1997. Event studies in economics and finance. Journal of Economic Literature, 35(1): 13-39.

NAUDÉ, W. 2009. The financial crisis of 2008 and the developing countries. Discussion Paper. World Institute for Development Economics Research.

RUF, B.M., MURALIDHAR, K., BROWN, R.M., JANNEY, J.J. \& PAUL, K. 2001. An empirical investigation of the relationship between change in corporate social performance and financial performance: A stakeholder theory perspective. Journal of Business Ethics, 32(2):143-156.

SARTORIUS, K. \& WOLMARANS, H.P. 2009. Corporate social responsibility: The financial impact of black economic empowerment transactions in South Africa. South African Journal of Economic and Management Sciences, 12(2):180-192.

SAUER, D.A. 1997. The impact of social-responsibility screens on investment performance: Evidence from the Domini 400 Social Index and Domini Equity Mutual Fund. Review of Financial Economics, 6(2): 137-149.

SCHRÖDER, M. 2007. Is there a difference? The performance characteristics of SRI equity indices. Journal of Business Finance \& Accounting, 34(1-2):331-348.

SEIFERT, B., MORRIS, S.A. \& BARTKUS, B.R. 2003. Comparing big givers and small givers: Financial correlates of corporate philanthropy. Journal of Business Ethics, 45(3):195-211.

STANWICK, P.A. \& STANWICK, S.D. 1998. The relationship between corporate social performance, and organizational size, financial performance, and environmental performance: An empirical examination. Journal of Business Ethics, 17(2):195-204.

STATMAN, M. 2000. Socially responsible mutual funds. Financial Analysts Journal, 56(3): 30-39.

VAN RENSBURG, P. \& ROBERTSON, M. 2003. Style characteristics and the cross-section of JSE returns. Investment Analysts Journal, 57:7-15.

VIVIERS, S., BOSCH, J.K., SMIT, E.v.D. M. \& BUIJS, A. 2008. The risk adjusted performance of responsible investment funds in South Africa. Investment Analysts Journal, 68:39-56.

VIVIERS, S., BOSCH, J.K., SMIT, E.v.D. M. \& BUIJS, A. 2009. Responsible investing in South Africa. Investment Analysts Journal, 69:3-16.

WARD, M. \& MULLER, C. 2010. The long term share price reaction to Black Economic Empowerment announcements on the JSE. Investment Analysts Journal, 71:27-36

WADDOCK, S.A. \& GRAVES, S.B. 1997. The corporate social performance-financial performance link. Strategic Management Journal, 18(4):303-319.

WRIGHT, P. \& FERRIS, S.P. 1997. Agency conflict and corporate strategy: The effect of divestment on corporate value. Strategic Management Journal, 18(1):77-83. 